\title{
Hehtolitrapainon ja lajikkeen vaikutus ohran rehuarvoon sikojen ruokinnassa
}

\author{
Maija-LiIsa Salo \\ Helsingin yliopiston kotieläintieteen laitos, 00710 Helsinki 71

\section{Effect of the volume weight and variety on the nutritive value of barley by pigs} \\ Maija-Lirsa Salo \\ Department of Animal Husbandry, University of Helsinki, 00710 Helsinki 71
}

\begin{abstract}
The digestibility of six barley batches were determined with pigs, live weight from 42 to $72 \mathrm{~kg}$, using a $3 \times 3$ Latin square pattern. Skimmilk powder, $16 \%$ of the diet, was as a protein supplement. The barleys consisted from four varieties, with a volume weight from 53 to $63 \mathrm{~kg} / \mathrm{hl}$, and the crude protein content from 10.5 to $12.8 \%$ of DM.

There were significant differences $(\mathrm{P}<0.05-0.01)$ between the poorest and the best bariey samples for the digestibilities of organic matter, crude protein and NFE. In nitrogen balances no significant differences appeared. The differences between barleys for the metabolizable and net energy values were $0-4 \%$. The low variation could be attributed to the quite constant composition of barleys, to the high negative correlation between the starch and crude protein contents, and to the positive correlation between the protein content and the digestibility of the protein.
\end{abstract}

\section{Johdanto}

Ohra on maamme tärkein rehukasvi. Eräs sen hyvistä ominaisuuksista on vakaa energia-arvo, niin vakaa että Kellner aikoinaan valitsi ohran rehuyksikköjärjestelmänsä perustaksi.

Ohran koostumukseen ja rehuarvoon ei mainittavasti vaikuta lajike, kasvupaikka, kohtuulliset säävauriot eikä liioin korjuun suorittaminen 2-3 viikkoa ennen tai jälkeen normaaliajan (Schulz ja OsLage 1969, Sundstøl 1970, MADSEN ym. 1972). Jos kuitenkin ohra korjataan selvästi vajaatuleentuneena, sen energia-arvo on sialla ja broilerilla merkitsevästi normaalia alempi, mutta märehtijällä ja aikuisella kanalla silloinkin vain hyvin vähän alempi (SUndstøl 1970, Тномке 1972). Jos hehtolitrapaino on hyvin matala, laskee energia-arvo myös munivalla kanalla (SiBBALd ja PRICE 1976).

Tämä tutkimus kohdistui kylmän ja sateisen kesän 1977 viljaan, mikä oli normaalia kevyempää. Tutkimus suoritettiin kaksiosaisena: jyvien fysi- 
kaalisiin ja kemiallisiin ominaisuuksiin perustuvana laajalla ohra- ja kauraaineistolla (SALO 1978) sekä tässä kirjoituksessa esitettävänä sulavuus- ja tasetutkimuksena.

\section{Aineisto ja menetelmät}

\section{Rehut}

Kokeessa oli kuusi ohraerää, mitkä edustivat neljää lajiketta. Niiden fysikaaliset ominaisuudet ja kemiallinen koostumus esitetään taulukossa 1. Viljat jauhettiin vasaramyllyllä $3 \mathrm{~mm}: n$ seulaa käyttäen. Samoihin eriin kuuluvilla ohrilla suoritettiin myöhemmin kasvatuskoe Hyvinkään sikakoeasemalla.

Valkuaistäydennykseksi käytetty rehumaitojauhe oli sumutuskuivattua ja sitä annettiin $16 \%$ rehuyhdistelmästä. Sulavuuslaskuissa maitojauheelle käytettiin rehutaulukossa ilmoitettuja sulavuuskertoimia: orgaaninen aine ja raakaproteiini $95 \%$, raakarasva $90 \%$ (ERIKSSON ym. 1972). Rehuyhdistelmän valkuaistaso oli noin $120 \mathrm{~g}$ srv/ry.

Kivennäis- ja vitamiiniseoksia annettiin normien mukaisesti.

\section{Koe-eläimet ja koeohjelma}

Kokeessa oli kuusi maatiasrotuista leikkoporsasta, jotka tuotiin Hyvinkään sikakoeasemalta. Niiden alkupainot olivat $40-45 \mathrm{~kg}$ ja loppupainot 70-73 kg. Siat saivat matolääkityksen kaksi päivää ennen kokeen alkua.

Siat olivat sulavuuskoehäkeissä. Koe suoritettiin kokonaiskeruumenetelmällä kahtena $3 \times 3$ latinalaisena neliönä. Ensimmäisellä koejaksolla totutuskausi oli 12 vrk, muilla jaksoilla 7 vrk. Keruukausi oli aina 5 vrk.

Siat saivat rehua eri jaksoilla $2.0,2.3 \mathrm{ja} 2.6 \mathrm{~kg} / \mathrm{pv}$, määrän nostaminen tapahtui uuden jakson alkaessa. Ruokinta suoritettiin kahdesti päivässä. Ohrajauho, rehumaitojauhe, kivennäisseos ja vitamiiniseos punnittiin kukin erikseen ja sekoitettiin. Jauhon päälle kaadettiin kaksinkertainen määrä vettä ja se sekoitettiin velliksi. Siat söivät heti kaiken rehun. Syönnin jälkeen niille

Taulukko 1. Sulavuuskokeen rehujen koostumus.

Table 1. The composition of feeds in digestibility trial.

\begin{tabular}{|c|c|c|c|c|c|c|c|c|}
\hline \multirow{2}{*}{$\begin{array}{l}\text { Ohra, lajike } \\
\text { Barley, variety }\end{array}$} & \multirow{2}{*}{$\begin{array}{c}\left.\text { Hl-paino }{ }^{1}\right)^{2} \text { ) } \\
\text { Volume weight } \\
\text { kg/h! }\end{array}$} & \multirow{2}{*}{$\begin{array}{c}\left.\text { 1000-jyvän p. }{ }^{1}\right) \\
1000-k r . w . \\
\mathrm{g}\end{array}$} & \multicolumn{6}{|c|}{$\%$ ka:sta $-\%$ of $D M$} \\
\hline & & & $\begin{array}{c}\text { r.prot. } \\
\text { cr. protein }\end{array}$ & $\begin{array}{r}\text { r.rasva } \\
\mathrm{cr} . \text { fat }\end{array}$ & $\begin{array}{l}\text { r.kuitu } \\
\text { cr. fibre }\end{array}$ & $\begin{array}{c}\text { tuhka } \\
\text { ash }\end{array}$ & $\begin{array}{c}\text { typett.u.a. } \\
\text { NFE }\end{array}$ & $\begin{array}{c}\text { tärkkelys } \\
\text { starch } \\
\end{array}$ \\
\hline 1 Otra $\ldots . . . . . .$. & $53.3(47.0)$ & 307 & 12.0 & 2.1 & 6.0 & 2.8 & 77.1 & 55.4 \\
\hline 2 Otra ............ & $58.7(51.5)$ & 34.0 & 12.6 & 2.2 & 5.0 & 2.6 & 77.6 & 57.1 \\
\hline 3 Suvi ............ & $58.8(54.6)$ & 30.1 & 12.8 & 2.1 & 5.3 & 2.9 & 76.9 & 55.5 \\
\hline 4 Etu $\ldots \ldots \ldots \ldots . . .$. & $57.2(56.3)$ & 35.6 & 12.3 & 2.1 & 4.8 & 2.7 & 78.1 & 57.4 \\
\hline 5 Etu $\ldots \ldots \ldots \ldots . .$. & $60.3(62.3)$ & 41.1 & 11.5 & 2.1 & 4.7 & 2.5 & 80.2 & 61.8 \\
\hline 6 Ingrid $\ldots . . . \cdots$ & $63.5(650)$ & 31.0 & 11.7 & 2.2 & 4.9 & 2.7 & 785 & 59.7 \\
\hline \multicolumn{3}{|c|}{ Kurrijauhe - Skimmilk powder } & 36.8 & 0.4 & & 8.1 & 54.7 & \\
\hline
\end{tabular}

1) Laskettu $87 \%$ :n ka-pitoisuudelle. - Calculated to $85 \%$ DM.

2) Sulkeissa tuottajan ilmoittamat hl-painot. - The volume weights measured by producer in parenthesis. 
tarjottiin vettä. Väliajoiksi kaukalot käännettiin nurin. Sikalan lämpötila oli $15-21^{\circ} \mathrm{C}$.

Sonta ja virtsa kerättiin aamuisin ja niistä otettiin analyysinäytteeksi tietty prosenttimäärä. Viimeisenä keruupäivänä kerättiin kaukalon edessä olevalta muovikalvolta sian syödessään roiskima rehu, mikä vähennettiin tähteenä. Virtsankeruuastiassa oli rikkihappoa pitämässä $\mathrm{pH}: \mathrm{n}$ 1-2 tienoilla.

\section{Määritykset}

Jauhojen ja sonnan kuiva-ainepitoisuus määritettiin kuivauskaapissa $103^{\circ} \mathrm{C}$ :ssa. Analyysinäytteeksi tulevat sontaerät kuivattiin vakuumikuivaajassa $40-50^{\circ}$ C:ssa. Jauhot ja sonnat jauhettiin $0.5 \mathrm{~mm}$ :n seulaa käyttäen.

Näytteistä tehtiin virallinen rehuanalyysi standardimenetelmiä käyttäen. Ohrista määritettiin lisäksi tärkkelys amyloglukosidaasimenetelmällä, kuitenkin ilman etanoliuuttausta, jotta jyvien vähäinen sokerimäärä (1-2\% ka:sta) saatiin mukaan (SALO ja SALMI 1968).

Jyvistä määritettiin hehtolitrapaino ja 1000 jyvän paino Valtion viljavaraston laitteita ja menetelmiä käyttäen.

Ryhmien väliset erot testattiin Tukey'n testillä.

\section{Tulokset ja tarkastelu}

Koeasemien ja rehutehtaan ennakkoilmoitus ohrien hehtolitrapainosta ei pitänyt yhtä omien mittausten kanssa, minkävuoksi ohraerien laatuerot jäivät tavoitetta pienemmiksi. Äärirajojen piti näet olla $47-65 \mathrm{~kg} / \mathrm{hl}$ ja kaikkien erien poiketa toisistaan (taul. 1, luvut sulkeissa), mutta omat mittaukset osoittivat vaihtelualueen pienemmäksi. Tulos oli omiaan vahvistamaan sitä tosiseikkaa, että hehtolitrapaino on sangen sovinnainen jyvien laadun mitta (LAmpinen 1977). Taulukossa 1 esitetyt painot ovat sikäli keskenään verrattavia, että ne ovat saman henkilön mittaustuloksia. Mittaukseen käytettyjen jyväerien ja jauhojen identtisyys testattiin lisäksi analysoimalla molemmat: tulokset olivat yhtäpitävät.

\section{Sulavuus ja rehuarvo}

Eri ohraerien koostumus oli lähes samanlainen (taul. 1), eikä liioin sulavuudessa ollut suuria eroja (taul. 2). Ohra n:o 1 oli koostumukseltaan selvimmin muita heikompaa ja myös sen sulavuus osoittautui merkitsevästi $(\mathrm{P}<$ $0.05-0.01)$ parhaita eriä huonommaksi. Viisi muuta sen sijaan poikkesi toisistaan vain mitättömän vähän.

Valkuaisen sulavuus noudatti johdonmukaisesti sääntöä, että sulavuus on positiivisessa riippuvuussuhteessa pitoisuuteen. Suurimman ja pienimmän pitoisuuden välinen sulavuusero oli merkitsevä $(\mathrm{P}<0.05)$. Rehuyksikköä kohti laskettuna sulavan raakavalkuaisen grammamääräiset erot muodostuivat melko suuriksi (taul. 3).

Kuidun sulavuuden todettiin vaihtelevan nollan molemmin puolin keskiarvon ollessa nollan luokkaa. Tulokset katsottiin niin epätarkoiksi, ettei niitä 
Taulukko 2. Kuuden ohraerän sulavuus lihasialla.

Table 2. The digestibilities of six barley batches by pigs.

\begin{tabular}{|c|c|c|c|c|c|c|}
\hline Ohra - Barley, no & $\begin{array}{c}\text { Sulavuude } \\
1\end{array}$ & $\begin{array}{l}\text { a standard } \\
2\end{array}$ & $\begin{array}{c}\text { oikkeamat, } \\
3\end{array}$ & $\frac{\%-\text { Dige }}{4}$ & $\begin{array}{c}\text { bilities and } \\
5\end{array}$ & $\begin{array}{c}\text { S.D., } \% \\
6\end{array}$ \\
\hline Orgaaninen aine & $77.5^{\mathrm{a}}$ & $81.8^{\mathrm{ab}}$ & $82.3^{\mathrm{ab}}$ & $82.5^{b}$ & $81.8^{\mathrm{ab}}$ & $83.1^{\mathrm{b}}$ \\
\hline Organic matter & \pm 1.8 & \pm 1.7 & \pm 0.6 & \pm 1.0 & \pm 0.8 & \pm 0.4 \\
\hline Raakaproteiinı & $73.1 \mathrm{ab}$ & $75.5^{\mathrm{ab}}$ & $77.3^{\mathrm{a}}$ & $74.6^{\mathrm{ab}}$ & $69.9^{b}$ & $71.2^{\mathrm{ab}}$ \\
\hline Crude protein & \pm 3.0 & \pm 4.2 & \pm 2.8 & \pm 3.9 & \pm 1.0 & \pm 1.1 \\
\hline Raakarasva & 70.4 & 69.3 & 70.5 & 71.3 & 71.7 & 68.9 \\
\hline Ether extract & \pm 7.0 & \pm 8.0 & \pm 2.6 & \pm 5.1 & \pm 4.7 & \pm 4.1 \\
\hline $\begin{array}{l}\text { Typett. uuteain. } \\
\text { NFE }\end{array}$ & $\begin{array}{l}87.6^{\mathrm{ac}} \\
\pm 1.0\end{array}$ & $\begin{array}{l}89.1^{\mathrm{abed}} \\
\pm 0.8\end{array}$ & $\begin{array}{l}89.2^{\mathrm{abed}} \\
\pm 0.6\end{array}$ & $\begin{array}{l}89.7^{\text {bed }} \\
\pm 0.2\end{array}$ & $\begin{array}{l}89.7^{\text {bed }} \\
\pm 0.3\end{array}$ & $\begin{array}{l}90.5^{\text {bd }} \\
\pm 0.8\end{array}$ \\
\hline
\end{tabular}

Keskiarvojen erot Tukey'n testillä testattuna - Differences betwcen means tested by Tukey's test: $\mathrm{a}-\mathrm{b}: \mathrm{P}<0.05, \mathrm{c}-\mathrm{d}: \mathrm{P}<0.01$.

Taulukko 3. Ohran muuntokelpoisen ja nettoenergian arvot sialla $(87 \%$ ka).

Table 3. Metabolizable (ME) and net energy (F.U.) values of six barley samples for pigs $(87 \%, D M)$.

\begin{tabular}{|c|c|c|c|c|c|c|}
\hline Ohra - Barley no & 1 & 2 & 3 & 4 & 5 & 6 \\
\hline 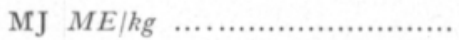 & 12.01 & 12.36 & 12.35 & 12.45 & 12.43 & 12.46 \\
\hline $\mathrm{Kg} / \mathrm{ry}-K g / F . U . \ldots \ldots \ldots \ldots \ldots \ldots$ & 1.07 & 1.04 & 1.04 & 1.03 & 1.03 & 1.03 \\
\hline Srv, g/ry - DCP, glF.U.* $\ldots \ldots .$. & 82 & 86 & 90 & 82 & 66 & 75 \\
\hline
\end{tabular}

${ }^{*} F . U .=0.7 \times$ starch units.

Taulukko 4. Typpitaseet eri ohradieeteillä.

Table 4. Nitrogen balances on different barley diets.

\begin{tabular}{|c|c|c|c|c|c|c|}
\hline Ohra - Barley, no & 1 & 2 & 3 & 4 & 5 & 6 \\
\hline N-tase, g N/pv ............... & 20.6 & 20.0 & 22.1 & 21.1 & 21.0 & 21.4 \\
\hline N-balance, $g$ N/d $\ldots \ldots \ldots \ldots \ldots \ldots \ldots \ldots \ldots \ldots \ldots$ & \pm 0.9 & \pm 1.6 & \pm 3.7 & \pm 5.6 & \pm 3.6 & \pm 1.2 \\
\hline
\end{tabular}

Erot eivät ole merkitseviä. - Differences are NS.

esitetä taulukossa. Kuitumääritys on siinä määrin sovinnainen, että näin vähäkuituisella rehulla raakakuidun sulavuus riippuu paljolti määrityksen suorittajasta.

Tärkkelyksen sulavuutta ei määritetty, koska aiemmissa tutkimuksissa on todettu, että sika sulattaa viljan tärkkelyksen täydellisesti (SALO 1965,"1971).

Taulukossa 3 esitetään todettujen sulavuuskertoimien perusteella virallista laskumallia käyttäen (Avon. 1969) lasketut muuntokelpoisen ja nettoenergian arvot. Huonoin ohra poikkesi parhaasta $4 \%$. Viiden muun väliset erot olivat 
vain $0-1 \%$. Energia-arvon vaihtelua eri ohraerien välillä vähentää se seikka, että kahden pääravintoaineen, tärkkelyksen ja raakaproteiinin välillä vallitsee ohrassa kiinteä negatiivinen vuorosuhde (SALO 1978). Pienen lisätasoituksen energia-arvoon tuo vielä se, että valkuaispitoisuuden noustessa myös valkuaisen sulavuus paranee.

Tuloksista voidaan todeta kokeen vahvistavan aiempaa tietoa, etteivät lajike-erot tai pienehköt hehtolitrapainovaihtelut vaikuta mainittavasti ohran energia-arvoon (Schulz ja Oslage 1969, Sundstøl 1970, Salo 1978). Valkuaispitoisuuden tiedetään vaihtelevan energia-arvoa enemmän (REKUNEN 1969, GaArbo Thomsen 1977, Peers ja TAylor 1977) ja kuten tässäkin kokeessa todettiin, valkuaisarvoa heikentää vielä se, että pitoisuuden laskiessa myös sulavuus laskee. Kysymyksessä ei ole yksin metabolisen typen vaikutus näennäiseen sulavuuteen, sillä sama voitiin todeta myös valkuaisen pepsiiniliukoisuudesta (SALO 1978).

\section{Typpitase}

Typpitaseessa ei ilmennyt merkitseviä eroja eri ohradieettien välillä. Ohran n:o 5 srv-pitoisuus oli tosin selvästi muita heikompi, mutta koska ohran valkuainen merkitsi keskimäärin vain $\mathbf{5 4 \%}$ dieetin sulavasta raakavalkuaisesta (46\% tuli rehumaitojauheesta), pieni ero ei vaikuttanut mitään typpitaseeseen.

\section{Tiivistelmä}

Kuuden ohraerän sulavuus määritettiin kahtena $3 \times 3$ latinalaisena neliönä lihasioilla painovälillä $42-72 \mathrm{~kg}$. Valkuaistäydennyksenä oli $16 \%$ rehumaitojauhetta yhdistelmästä.

Ohrat käsittivät neljä lajiketta ja niiden hehtolitrapainot vaihtelivat $53-63 \mathrm{~kg} / \mathrm{hl}$ ja raakaproteinipitoisuudet $10.5-12.8 \%$ ka:sta.

Heikoimman ja parhaan ohran orgaanisen aineen, raakaproteiinin ja typettömien uuteaineiden sulavuuksien välinen ero oli merkitsevä $(\mathrm{P}<0.05-$ 0.01). Typpitaseessa ei ilmennyt merkitsevää eroa. Muuntokelpoisen ja nettoenergian kohdalla eri ohraerät poikkesivat toisistaan $0-4 \%$. Pienten koostumusmuutosten vaikutusta energia-arvoon vähentää ohralle ominainen tärkkelys- ja raakaproteiinipitoisuuden välillä vallitseva negatiivinen vuorosuhde ja vähän myös raakaproteiinin pitoisuuden ja sulavuuden välinen positiivinen vuorosuhde.

\section{KIRJALLISUUSLUETTELO}

Anon. NJF's Fodermiddeltabel. 1969. 40 p. Gjøvik.

Eriksson, S., SANne, S. \& Thomke, S. 1972. Fodermedlen. 251 p. Borås.

GaArbo Thomsen, M. 1977. Bygsorters fodervaerdi til slagtekyllinger. 460. Beretn. Statens Husdyrbrugs forsøg. 60 p. København.

LAMPINEN, R. 1977. Hehtolitrapaino viljan laadun mittana. Käytännön maamies 12/1977: $26-28$.

Madsen, A., Bengtsson, A., Kivi, E. \& Mrkkelsen, K. 1972. Høsttidspunktets indflydelse på byggens fodervaerdi. 395. Bertn. Forsøgslab. 128 p. København. 
PeErs, D. G. \& TAYLOR, A. G. 1977. The influence of the variety of bariey and level of nitrogen fertilisation on the digestibility and metabolisable energy value of barley meal in the pig. J. Sci. Fd. Agric. 28: 602-606.

REKUNEN, M. 1969. Ohran lajikkeet ja raakavalkuainen. Hankk'jan saroilta 10, 1969.

SALO, M.-L. 1965. Determination of carbohydrate fractions in animal foods and faeces. Acta Agric. Fenn. 105: 1-102.

- 1971. Inverkan av havremjölets finhetsqrad på dess smältbarhet hos svin. NJFKongressen 29. juni - 2. juli 1971. Seksjon V. p. 113-114.

- 1978. Relationships between physical and chemical characteristics and calculated metabolizable energy values on barley and oats with highly variable volume weights. J. Scient. Agric. Soc. Finl. 50: 276-284.

- \& Salmi, N. 1968. Detemination of starch by the amyloglucosidase method. J. Scient. Agric. Soc. Finl. 40: 38-45.

Schulz, E. \& Oslage, H. J. 1969. Untersuchungen über den Nährwert verschiedener in- und ausländischer Gersten für Schweine. Landw. Forsch. 22: 265-280.

Sibbald, I. R. \& Price, K. 1976. Relationships between metabolizable energy values for poultry and some physical and chemical data describing Canadian wheats, oats and barleys. Can. J. Anim. Sci. 56. 255-268.

SundsTøL, F. 1970. Undersøkelser over fôrverdien av bygg av ulik kvalitet. Beretn. nr. 140. Landbrugshøgsk. Foringsforsøk. Norges Landbrukshøgsk. 61 p.

Тномке, S. 1972. On the influence of different stages of ripeness on the productive value of barley fed to chickens, laying hens, rats and mice. Acta Agric. Scand. 22: 107-120.

Käsikirjoitus saapunut 7. 7.1978. 